\title{
OPTIMISATION OF GOVERNMENTAL DECISIONS
}

\author{
Ginta Uzulina \\ Ministry of Agriculture, 2 Republikas laukums, Riga, LV-1981 Latvia, \\ e-mail: ginta.uzulina@zm.gov.lv
}

Received: 4 March, 2003

\begin{abstract}
The report discusses the role of impact assessment and evaluation of governmental decisions. The main objective of report is to develop a statistical model for optimisation of the set of policy instruments. The Draft of Rural Development Plan is used as example in order to develop and test the statistical model for optimising the allocation and use of funds. The statistical model is developed like as a small software version for policy-makers to evaluate critical decisions. The statistical decision making theory is used in seeking solutions to optimise the choice of governmental decisions. The functions of losses or gains are defined on the basis of statistical data in two levels - macroeconomic level and microeconomic level. In the statistical model the principles of the subjective probability are also applied in the case of unreliable and unavailable information.
\end{abstract}

Keywords: decision analysis, government, strategic planning, optimal decision

\section{Policy-making process for rural development}

The analysis and statistical models are necessary to draft and implement effective policy for specific problems. In policy-making process should be taken into account the several steps: an identification of problem, a formulation of policy, an implementation of policy and an effect of policy. The identification of problem means that government should identifies the fields, where these problems exist and where is necessary solution. The formulation of policy is set of targets, which should be achieved. The implementation of policy means that policy-makers choose instruments for achieving targets. And finally, the last step is to fixed results of policy, which should be realised. All these steps should be harmonised in order to provide effective policy. And it is necessary also for a Draft of Rural Development Plan, which will be one of policy documents for rural development.

In current moment the candidate countries have drafted different documents for rural and structural development. For example, in Latvia two drafts are prepared - the Draft of Rural Development Plan and a Draft of Single Programme Document for structural funds, which will be in force from 2004 to 2006. In European Union (EU) such documents are usually drafted for 7 years period but the candidate countries should develop it for shorter period because the accession time is planned in middle of 7 years budget period. EU has defined certain amount of finance for rural development measures, as well as for structural measures. Each country has a choice to allocate fixed amount for each measure for rural development in framework of total amount of finance, as well as to define special criteria for these measures. The EU legislation provides guidelines for these measures but Latvia and other countries should set details and choices. In general the criteria are aimed on special target groups, which are entitled to receive support. The main measures and targets of the Draft of Rural Development Plan of Latvia are shown in Table 1.

These measures of the Draft of Rural Development Plan are used for the statistical model. There is set of measures, where measure $\mathrm{C}$ has several sub-measures $\mathrm{C} 1, \mathrm{C} 2, \mathrm{C} 3, \mathrm{C} 4$ and $\mathrm{C} 5$. For each measure is defined 
Table 1. Measures and targets of the Draft of Rural Development Plan in Latvia

\begin{tabular}{|c|c|c|}
\hline & Measure & Target \\
\hline A & Early retirement & $\begin{array}{l}\text { To promote involvement of young people in rural economy and provide income for } \\
\text { older farmers }\end{array}$ \\
\hline B & Less favourite area & $\begin{array}{l}\text { To facilitate the economical activities, employment, income and welfare for } \\
\text { inhabitants in area, in which are limited possibilities to increase income of rural } \\
\text { household due to less favourite climatic conditions. }\end{array}$ \\
\hline $\mathrm{C}$ & Agro-environment & $\begin{array}{l}\text { To implement and to promote the methods of farming, which are friendly to } \\
\text { environment, which preserve rural landscape and to promote producing of } \\
\text { qualitative organic products. }\end{array}$ \\
\hline $\mathrm{D}$ & $\begin{array}{l}\text { Afforestation of agricultural } \\
\text { lands }\end{array}$ & $\begin{array}{l}\text { To facilitate use of less fertile and unutilised agricultural lands, to promote } \\
\text { improvement of rural landscape. }\end{array}$ \\
\hline $\mathrm{E}$ & Support for producer groups & $\begin{array}{l}\text { To facilitate a formation of producer groups to provide effective agricultural } \\
\text { production, primary processing and marketing, decreasing costs of production. }\end{array}$ \\
\hline $\mathrm{F}$ & $\begin{array}{l}\text { Support for subsistence } \\
\text { farming }\end{array}$ & $\begin{array}{l}\text { To speed up structural changes in rural economy, to facilitate development of } \\
\text { activities in non-agricultural sector, to increase employment in rural areas. }\end{array}$ \\
\hline
\end{tabular}

target, which is necessary to evaluate impact of measure. The certain amount of finance is planned for each measure in order to achieve defined target, as well as set the special criteria to define the target group for support. These criteria and finance are enclosed in the statistical model in order to estimate losses and gains for each measure. All these criteria and measures included in this special document, which is organised as a set of policy decisions and which will be implemented after approval of government. This Draft is used as example in order to develop and test the statistical model for optimising of allocation of funds and to give recommendations for further improvement of the policy decisions.

\section{Development of statistical model}

\subsection{Basic principles and the framework of the statistical model}

The basic data for the statistical model is data from the Draft of Rural Development Plan; as well as available statistical information is used [1]. The first step to develop statistical model is clarification of targets for each measure in order to define the possible gains in result of policy. It is necessary to oversee all steps of policy-making process in order to develop appropriate statistical model for optimisation of decisions. The framework of this statistical model is shown in Figure $1[2,3]$.

Fig. 1. The framework of statistical model

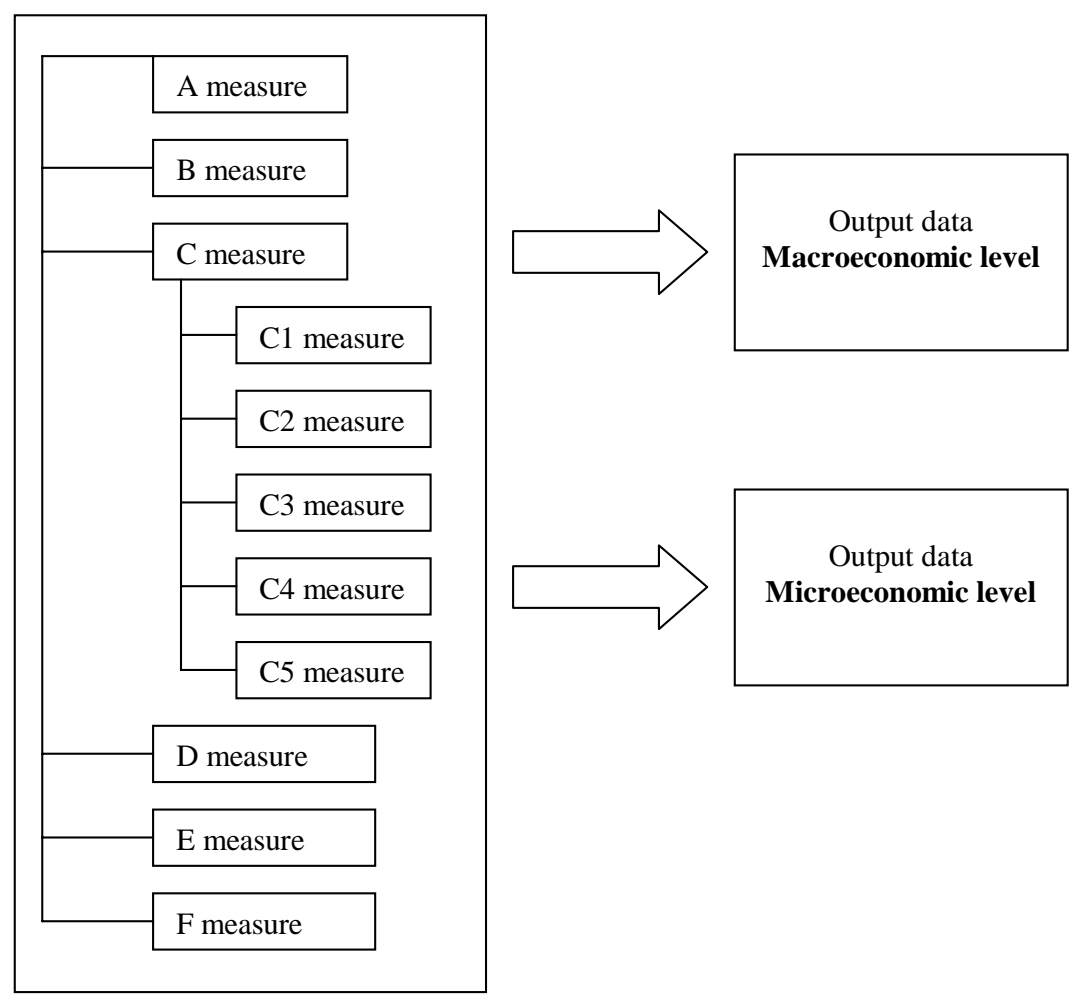


There are three main parts of this model: input data, data processing and output data. The main idea of the statistical model is to quantify the targets as the functions of gains for each measure, which are included in part of data processing, as well as to quantify criteria for each measure in input part of the model. For each measure is developed sub-model of data processing because the measures are different. The main factor for such model, the functions of gains should be comparable. And it is most of difficult tasks for developing such model due to different measures. The statistical model is developed as software version, which is useful in policy-making process to evaluate the different options of governmental decisions.

\subsection{Input data of the statistical model}

The main input data are allocated finance, and criteria (Table 2), which is used as limit for target group (recipients). There is already draft of allocation of EU funds by each measure in the Draft of Rural Development Plan. Accordingly the requirements of EU, the finance from EU funds should be allocated for each measure as $80 \%$ of total amount of finance. It means that $20 \%$ of finance should be provided by national funds. The preliminary draft of allocation of EU funds is planned and the provisional figures are put in the statistical model as input data.

Target groups are calculated as the number of recipients, which have rights for support under each measure. The quantitative values are put into statistical model. The first, the maximum number of recipients is put in the model, and then all criteria are included in the model, which are used as coefficient for corrections of maximum number of recipients. In case of unreliable or unavailable information the subjective probability is used, for example, to define expected target group of measure, or to define function of losses (or gains). Subjective opinion is used as a prior probability. A posterior probability is new value, which gained after correcting subjective opinion with new information, in case of this statistical model corrections are made by past observations for similar measures or by extrapolation.

Values $F$, where $1,2, \ldots$ i means that allocated finance for certain measure and $1,2, \ldots$ j means year for which finance is allocated in period from 2004 to 2006.

Criteria for uses of finance $-a_{1 j}, b_{1 j}, c_{1 j}, \ldots .$. defined more than one, where $1,2, \ldots 1$ means criteria for each measure and $1,2, \ldots$ j means that for one measure could be defined several sub-criteria, which influence value of target group, as well as could be fixed as amount of support.

\subsection{Data processing in the statistical model}

The main part of the statistical model is data processing - in this part for each sub-model of measure are developed specific mathematical equations in order to estimate possible gains and losses. The functions of gains or losses are defined by principles of the decision-making theory, where function of losses (or gains) is $\mathbf{L}(\mathbf{q}, \mathbf{a})$. The action $\mathbf{a}$ includes set of criteria for each measure and possible consequences in result of action are $(\mathbf{q}, \mathbf{a})$. Accordingly the decision-making theory it is possible to define the function of risk $\mathbf{R}$ with range QxD and range of values $\mathbf{R}$ taking decision $\mathbf{d}$, when the situation is q. Accordingly the decision-making theory we have to find such decision, which is optimal of all space of decisions D. It means that it is necessary to search such decision function for which maximum value of risk is equal to the less possible maximum risk.

The function of gains or losses are developed enclosing different conditions, which will be influenced by this measure. For example, in Measure A-Early retirement - one of gains could be that realisation of commodities would increased because average income per household could increase. Then it is possible that

Table 2. Input data for the statistical model [4]

\begin{tabular}{|c|c|c|c|c|c|c|c|c|c|c|c|c|c|}
\hline & \multirow{2}{*}{$\begin{array}{c}\text { Allocated } \\
\text { finance,ME- } \\
\text { UR }\end{array}$} & \multirow{2}{*}{$\begin{array}{l}\text { Maximum } \\
\text { number of } \\
\text { recipients }\end{array}$} & \multirow{2}{*}{$\begin{array}{c}\text { Corrected } \\
\text { number of } \\
\text { recipients }\end{array}$} & \multicolumn{10}{|c|}{ Coefficient for estimation of target group (recipients) } \\
\hline & & & & K11 & K12 & K13 & K14 & K15 & K21 & K22 & $\mathrm{K} 23$ & K24 & K25 \\
\hline $\mathrm{A}$ & $F_{1 j}$ & $\mathrm{x}_{1 \mathrm{j}}$ & $\mathrm{y}_{1 \mathrm{j}}$ & $a_{1 j}$ & $\mathrm{~b}_{1 \mathrm{j}}$ & $\mathrm{c}_{1 \mathrm{j}}$ & $\mathrm{D}_{1 \mathrm{j}}$ & $\mathrm{e}_{1 \mathrm{j}}$ & $\mathrm{f}_{1 \mathrm{j}}$ & $\mathrm{g}_{1 \mathrm{j}}$ & $\mathrm{h}_{1 \mathrm{j}}$ & $\mathrm{m}_{1 \mathrm{j}}$ & $\mathrm{n}_{1 \mathrm{j}}$ \\
\hline $\mathrm{B}$ & $\mathrm{F}_{2 \mathrm{j}}$ & $x_{2 j}$ & $\mathrm{y}_{2 \mathrm{j}}$ & $a_{2 j}$ & $\mathrm{~b}_{2 \mathrm{j}}$ & $\mathrm{c}_{2 \mathrm{j}}$ & $D_{2 j}$ & $\mathrm{e}_{2 \mathrm{j}}$ & $\mathrm{f}_{2 \mathrm{j}}$ & $\mathrm{g}_{2 \mathrm{j}}$ & $\mathrm{h}_{2 \mathrm{j}}$ & $\mathrm{m}_{2 \mathrm{j}}$ & $\mathrm{n}_{2 \mathrm{j}}$ \\
\hline $\mathrm{C}$ & $\mathrm{F}_{3 \mathrm{j}}$ & $x_{3 j}$ & $\mathrm{y}_{3 \mathrm{j}}$ & $a_{3 j}$ & $\mathrm{~b}_{3 \mathrm{j}}$ & $\mathrm{c}_{3 \mathrm{j}}$ & $\mathrm{D}_{3 \mathrm{j}}$ & $\mathrm{e}_{3 \mathrm{j}}$ & $\mathrm{f}_{3 \mathrm{j}}$ & $\mathrm{g}_{3 \mathrm{j}}$ & $\mathrm{h}_{3 \mathrm{j}}$ & $\mathrm{m}_{3 \mathrm{j}}$ & $\mathrm{n}_{3 \mathrm{j}}$ \\
\hline $\mathrm{D}$ & $\mathrm{F}_{4 \mathrm{j}}$ & $\mathrm{X}_{4 \mathrm{j}}$ & $\mathrm{y}_{4 \mathrm{j}}$ & $\mathrm{a}_{4 \mathrm{j}}$ & $\mathrm{b}_{4 \mathrm{j}}$ & $\mathrm{c}_{4 \mathrm{j}}$ & $\mathrm{D}_{4 \mathrm{j}}$ & $\mathrm{e}_{4 \mathrm{j}}$ & $\mathrm{f}_{4 \mathrm{j}}$ & $\mathrm{g}_{4 \mathrm{j}}$ & $\mathrm{h}_{4 \mathrm{j}}$ & $\mathrm{m}_{4 \mathrm{j}}$ & $\mathrm{n}_{4 \mathrm{j}}$ \\
\hline $\mathrm{E}$ & $\mathrm{F}_{5 \mathrm{j}}$ & $\mathrm{x}_{5 \mathrm{j}}$ & $\mathrm{y}_{5 \mathrm{j}}$ & $a_{5 j}$ & $\mathrm{~b}_{5 \mathrm{j}}$ & $\mathrm{c}_{5 \mathrm{j}}$ & $\mathrm{D}_{5 \mathrm{j}}$ & $\mathrm{e}_{5 \mathrm{j}}$ & $\mathrm{f}_{5 \mathrm{j}}$ & $\mathrm{g}_{5 \mathrm{j}}$ & $\mathrm{h}_{5 \mathrm{j}}$ & $\mathrm{m}_{5 \mathrm{j}}$ & $\mathrm{n}_{5 \mathrm{j}}$ \\
\hline $\mathrm{F}$ & $F_{6 j}$ & $\mathrm{x}_{6 \mathrm{j}}$ & $\mathrm{y}_{6 \mathrm{j}}$ & $a_{6 j}$ & $\mathrm{~b}_{6 \mathrm{j}}$ & $\mathrm{c}_{6 \mathrm{j}}$ & $\mathrm{D}_{6 \mathrm{j}}$ & $\mathrm{e}_{6 \mathrm{j}}$ & $\mathrm{f}_{6 \mathrm{j}}$ & $\mathrm{g}_{6 \mathrm{j}}$ & $\mathrm{h}_{6 \mathrm{j}}$ & $\mathrm{m}_{6 \mathrm{j}}$ & $\mathrm{n}_{6 \mathrm{j}}$ \\
\hline
\end{tabular}


in model the following assumption is put: an amount of sold commodities will increased by $5 \%$ due to increasing of income in rural area. It could be use as a prior probability and then it could be corrected using new information. And new information could be found estimating correlation and regression equation between amount of sold commodities and income level.

The calculations of the functions of gains and losses for each measure are defined differently but they are expressed as financial gains, in order to estimate the gains between these measures. The part of data processing is divided in two types of calculations in macroeconomic and microeconomic level.

\subsection{Output data and interpretation of results}

The one part of results is data output in macroeconomic level (Table 3 ). There is included the allocated finance and it is linked with input data in order to see expected gains and allocation of finance for each measure. In addition, the main outcome of statistical model is the function of gains and losses and they show development in economy.

The function of gains is defined as $\mathrm{G}(\mathrm{q}, \mathrm{d}(\mathrm{x})$ ), where $1,2, \ldots$ i means the gains for $\mathrm{i}$-measure and $1,2, \ldots . \mathrm{j}$ means gains in $\mathrm{j}$-year.

The function of losses is defined as $\mathrm{L}(\mathrm{q}, \mathrm{d}(\mathrm{x}))$, where $1,2, \ldots$ i means the expected losses for i-measure and $1,2, \ldots . j$ means the losses in $\mathrm{j}$-year.

In the statistical model the value of expected results for each i-measure and in j-year are also included. These values are included because the Draft of Rural Development Plan defines such results. They are needed to estimate quality of the Draft. In some cases using this statistical model and clarifying the quantitative value of target group it is possible to see that some of criteria should be revised.
The function of gains for each measure should be comparable with others, and if the functions of gains are similar and it is difficult to decide, which choice of criteria and allocated funds will be optimal, then there is other solution - to supplement the statistical model with output in microeconomic level. For example, measure $\mathrm{C}$ - Agro-environment, this measure could give macroeconomic results in long time and if the gains is smaller as it is in case for other measures, it is better to estimate gains in microeconomic level too - what average income (gains) will be for one farm or household. Then it is necessary to include several types of farms in the statistical model, in order to estimate the gains in microeconomic level. And for each type of farms has distribution density, which depends on many factors - criteria of measure, support level or instrument used for specific measure, as well as size of farm, regional location and others factors. All these factors are included in part of data processing. The density it is important element of output part because it shows - how is measure important. For example, if the average income or gains for measure $\mathrm{A}$ are higher than average income for measure $\mathrm{C}$, then it is necessary to compare, how many will farms be influenced by these measures. If only $5 \%$ of total number of farms will be high income in case of measure $\mathrm{A}$, and if income is lower for measure $\mathrm{C}$ but number of farms will be $80 \%$ with such income and difference between average income of measures $\mathrm{A}$ and $\mathrm{C}$ is not too big, then it is useful to consider as good set of decisions for measure C. The framework of output data in microeconomic level is shown in Table 4.

\section{Conclusions}

There are several advantages in this statistical model:

- It clarifies the positive feature or weaknesses in strategic programmes and identifies the areas of decisions space, which should be improved or revised.

Table 3. Framework of output data in macroeconomic level

\begin{tabular}{|c|c|c|c|c|c|}
\hline Measure & Allocated finance & Target group & Gains & Losses & Expected results \\
\hline A & $F_{1 j}$ & $x_{1 j}$ & $\mathrm{G}_{1 \mathrm{j}}$ & $\mathrm{L}_{1 \mathrm{j}}$ & $E_{1 j}$ \\
\hline B & $\mathrm{F}_{2 \mathrm{j}}$ & $x_{2 j}$ & $\mathrm{G}_{2 \mathrm{j}}$ & $\mathrm{L}_{2 \mathrm{j}}$ & $E_{2 j}$ \\
\hline $\mathrm{C}$ & $\mathrm{F}_{3 \mathrm{j}}$ & $\mathrm{x}_{3 \mathrm{j}}$ & $\mathrm{G}_{3 \mathrm{j}}$ & $\mathrm{L}_{3 \mathrm{j}}$ & $E_{3 j}$ \\
\hline $\mathrm{D}$ & $\mathrm{F}_{4 \mathrm{j}}$ & $\mathrm{X}_{4 \mathrm{j}}$ & $\mathrm{G}_{4 \mathrm{j}}$ & $\mathrm{L}_{4 \mathrm{j}}$ & $E_{4 j}$ \\
\hline $\mathrm{E}$ & $\mathrm{F}_{5 \mathrm{j}}$ & $\mathrm{x}_{5 \mathrm{j}}$ & $\mathrm{G}_{5 \mathrm{j}}$ & $\mathrm{L}_{5 \mathrm{j}}$ & $\mathrm{E}_{5 \mathrm{j}}$ \\
\hline $\mathrm{F}$ & $\mathrm{F}_{6 \mathrm{j}}$ & $\mathrm{x}_{6 \mathrm{j}}$ & $\mathrm{G}_{6 \mathrm{j}}$ & $\mathrm{L}_{6 \mathrm{j}}$ & $\mathrm{E}_{6 \mathrm{j}}$ \\
\hline
\end{tabular}


Table 4. Framework of output data in microeconomic level

\begin{tabular}{|c|c|c|c|c|c|c|c|c|}
\hline & \multicolumn{2}{|c|}{ Farm type A } & \multicolumn{2}{c|}{ Farm type B } & \multicolumn{2}{c|}{ Farm type C } & \multicolumn{2}{c|}{ Farm type D } \\
\cline { 2 - 10 } & $\begin{array}{c}\text { Average } \\
\text { income, } \\
\text { EUR }\end{array}$ & $\begin{array}{c}\text { Number of } \\
\text { farms }\end{array}$ & $\begin{array}{c}\text { Average } \\
\text { income, } \\
\text { EUR }\end{array}$ & $\begin{array}{c}\text { Number of } \\
\text { farms }\end{array}$ & $\begin{array}{c}\text { Average } \\
\text { income, } \\
\text { EUR }\end{array}$ & $\begin{array}{c}\text { Number of } \\
\text { farms }\end{array}$ & $\begin{array}{c}\text { Average } \\
\text { income, } \\
\text { EUR }\end{array}$ & $\begin{array}{c}\text { Number of } \\
\text { farms }\end{array}$ \\
\hline $\mathrm{A}$ & $\mathrm{S}_{11}$ & $\mathrm{~W}_{11}$ & $\mathrm{~S}_{12}$ & $\mathrm{~W}_{12}$ & $\mathrm{~S}_{13}$ & $\mathrm{~W}_{13}$ & $\mathrm{~S}_{14}$ & $\mathrm{~W}_{14}$ \\
\hline $\mathrm{B}$ & $\mathrm{S}_{21}$ & $\mathrm{~W}_{21}$ & $\mathrm{~S}_{22}$ & $\mathrm{~W}_{22}$ & $\mathrm{~S}_{23}$ & $\mathrm{~W}_{23}$ & $\mathrm{~S}_{24}$ & $\mathrm{~W}_{24}$ \\
\hline $\mathrm{C}$ & $\mathrm{S}_{31}$ & $\mathrm{~W}_{31}$ & $\mathrm{~S}_{32}$ & $\mathrm{~W}_{32}$ & $\mathrm{~S}_{33}$ & $\mathrm{~W}_{33}$ & $\mathrm{~S}_{34}$ & $\mathrm{~W}_{34}$ \\
\hline $\mathrm{D}$ & $\mathrm{S}_{41}$ & $\mathrm{~W}_{41}$ & $\mathrm{~S}_{42}$ & $\mathrm{~W}_{42}$ & $\mathrm{~S}_{43}$ & $\mathrm{~W}_{43}$ & $\mathrm{~S}_{44}$ & $\mathrm{~W}_{44}$ \\
\hline $\mathrm{E}$ & $\mathrm{S}_{51}$ & $\mathrm{~W}_{51}$ & $\mathrm{~S}_{52}$ & $\mathrm{~W}_{52}$ & $\mathrm{~S}_{53}$ & $\mathrm{~W}_{53}$ & $\mathrm{~S}_{54}$ & $\mathrm{~W}_{54}$ \\
\hline $\mathrm{F}$ & $\mathrm{S}_{61}$ & $\mathrm{~W}_{61}$ & $\mathrm{~S}_{62}$ & $\mathrm{~W}_{62}$ & $\mathrm{~S}_{63}$ & $\mathrm{~W}_{63}$ & $\mathrm{~S}_{64}$ & $\mathrm{~W}_{64}$ \\
\hline
\end{tabular}

- It is useful to develop such statistical model because it improves the quality of governmental decisions, which are planned for long term period, for example as it is in case of Rural Development Plan. It is better to predict consequences and impact of decision in drafting process and avoid costly and time-consuming corrections and improvements in implementation phase of policy.

- The statistical model identifies weaknesses in programming of policy and shows necessary improvements for drafting governmental documents in future.

- Using the functions of gains and losses, it is possible to find optimal decisions and to take final decision regarding allocation of finance, criteria or set of instruments, in order to achieve defined targets in most efficient way.

- The functions of gains in microeconomic level assist to find the optimal decision in cases if the gains or losses in macroeconomic level are similar and it is difficult to do choice using only output data of macroeconomic level.

- The statistical model is useful tool for policymakers in evaluation of critical decisions. The framework and principles of the statistical model can be used for evaluation of other similar governmental decisions or strategic programmes, for example, for optimisation of EU structural funds.

There are also disadvantages in this statistical model:

- The statistical model is time-consuming and the Draft of Rural Development Plan has different measures. Therefore it is difficult developing stage of the statistical model.

- Many of measures for rural development are new and there are not available indicators to estimate the impacts of these measures for rural develop- ment, especially regarding environmental measures. Therefore in the statistical model are a lot of gaps in information space, which are filled with subjective assumptions.

Finally, to continue study regarding the developing of this statistical model, it could be useful to modify the statistical model with supplementary part - observations results, which comprise mains results of observations and which are influencing functions of gains. These values will be used as posterior information for correction assumptions in the statistical model. It could be useful to add the different types of results in order to provide more flexible model for any changes in governmental decisions. For example, if we have new decision to change some criteria or reallocation of finance then it is necessary to estimate impact of decision and find new optimal solution. In this case policymaker can used posterior information from part of observations results of the model. As well as, the next step in the further studies should be an estimation of parameters of the model to improve reliability and quality of the model.

\section{References}

1. Chatfield C. Problem Solving A Statisticians Guide, Texts in Statistical Science. Chapman \& Hall (2 ed) (1995), 82-88.

2. Hashem Pesaran M., Wickens M.R. Handbook of Applied Econometrics Volume I: Macroeconomics, Blackwell Publishers Ltd. (1999), 313-350.

3. Lloyd E., Ledermann W., Handbook of Applicable Mathematics, Part B (in Russian), Moscow - 1990, 375-419.

4. Provisional results of Agricultural Census 2001, Central Statistical Bureau of Latvia (2002), 11-38. 